\title{
Dexamethasone reduces postoperative vomiting and pain after pediatric tonsillectomy
}

\section{[La dexaméthasone réduit les vomissements et la douleur postopératoires après une} amygdalectomie pédiatrique]

\author{
Mokhtar Elhakim MD, Naglaa M. Ali MD, Inas Rashed MD, Mostafa K. Riad MD, Mona Refat MD
}

Purpose: Previous studies on dexamethasone's antiemetic and analgesic potential in children undergoing tonsillectomy have produced conflicting results. The aim of this study was to evaluate the effects of a single dose of dexamethasone on the incidence and severity of postoperative vomiting and pain in children undergoing electrocautery tonsillectomy under standardized general anesthesia.

Methods: In a double-blinded study, 120 patients were randomly allocated to receive either dexamethasone $0.5 \mathrm{mg} \cdot \mathrm{kg}^{-1}$ (maximum dose $8 \mathrm{mg}$ ) iv or an equivalent volume of saline preoperatively. The incidence of early and late vomiting, need for rescue antiemetics, time to first oral intake, time to first demand of analgesia and analgesic consumption were compared in both groups. Pain scores used included Children's Hospital Eastern Ontario Pain Scale, "faces", and a 0-10 visual analogue pain scale.

Results: Compared with placebo, dexamethasone significantly decreased the incidence of early and late vomiting $(P<0.05, P<$ 0.001 respectively). Fewer patients in the dexamethasone group needed antiemetic rescue $(P<0.01)$. The time to first oral intake was shorter, and the time to first dose of analgesic was longer in the dexamethasone group $(P<0.0 \mathrm{I})$. Pain scores $30 \mathrm{~min}$ after extubation were lower $(P<0.05)$ in the dexamethasone group. At 12 and $24 \mathrm{hr}$ postoperative swallowing was still significantly less painful in the dexamethasone group than in the control group $(P<0.0$ I $)$.

Conclusion: Preoperative dexamethasone $0.5 \mathrm{mg} \cdot \mathrm{kg}^{-1}$ iv reduced both postoperative vomiting and pain in children after electrocautery tonsillectomy.

\footnotetext{
Objectif : Les études antérieures sur le potentiel analgésique et antiémétique de la dexaméthasone, chez des enfants qui subissent une amygdalectomie, ont donné des résultats contradictoires. Nous voulions évaluer les effets d'une dose unique de dexaméthasone sur l'incidence et la sévérité des vomissements et de la douleur postopératoires chez des enfants qui subissent une amygdalectomie par électrocautérisation sous anesthésie générale normalisée.
}

Méthode : Dans l'étude à double insu, 120 patients ont été répartis au hasard et ont reçu, avant l'opération, soit $0,5 \mathrm{mg} \cdot \mathrm{kg}^{-1}$ de dexaméthasone iv (dose maximale de $8 \mathrm{mg}$ ), soit un volume équivalent de solution saline. L'incidence de vomissements précoces et tardifs, le besoin d'antiémétiques de secours, le temps précédant la première absorption orale et la première demande d'analgésie, et la consommation d'analgésique ont fait l'objet de comparaison intergroupe. Les scores de douleur utilisés comprenaient la Children's Eastern Ontario Pain Scale, l'échelle des "mimiques" et une échelle visuelle analogique cotée de 0 à 10.

Résultats : Comparée au placebo, la dexaméthasone a significativement réduit l'incidence de vomissements précoces et tardifs $(P<$ $0,05, P<0,00$ I respectivement). Peu de patients ayant reçu la dexaméthasone ont eu besoin d'antiémétique de secours $(P<0,0$ I). Le temps précédant la première absorption orale a été plus court et le temps précédant la première dose d'analgésique a été plus long avec la dexaméthasone $(P<0,01)$. Les scores de douleur, 30 min après l'extubation, ont été plus bas $(P<0,05)$ avec la dexaméthasone aussi. À 12 et 24 h après l'opération, la dég/utition a été significativement moins douloureuse chez les enfants qui ont eu la dexaméthasone que chez les enfants témoins $(P<0,01)$.

Conclusion : L'administration iv préopératoire de $0,5 \mathrm{mg} \cdot \mathrm{kg}^{-1}$ de dexaméthasone a réduit les vomissements et la douleur postopératoires chez des enfants qui ont subi une amygdalectomie par électrocautérisation.

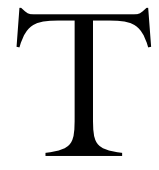

ONSILLECTOMY is one of the most frequently performed ambulatory surgical procedures in children and is associated with an incidence of postoperative vomiting ranging between $40 \%$ and $73 \% .^{1-3}$ The introduction of an electrodissection surgical technique has virtually eliminated immediate postoperative hemorrhage. However, it may cause more pain, discomfort

From the Department of Anesthesia, Faculty of Medicine, Ain-Shams University, Cairo, Egypt.

Address correspondence to: Dr. Mokhtar Elhakim, Al Horreya Heliopolis, Code No: 11361, P.O. Box: 2361, Cairo, Egypt.

Phone: 202-271-6141; Fax: 202-271-6141; E-mail: mokhtare_h@hotmail.com

Accepted for publication September 30, 2002.

Revision accepted December 13, 2002. 
and poor oral intake due to more local inflammation, nerve irritation and laryngeal muscle spasm. ${ }^{4}$

Dexamethasone has been used as an antiemetic drug in patients undergoing chemotherapy with limited side effects. ${ }^{5}$ Recently, it has been found to have a prophylactic effect on postoperative vomiting in children undergoing tonsillectomy. ${ }^{6}$ Dexamethasone has combined antiemetic and anti-inflammatory effects that may decrease postoperative tissue injury, edema and pain after electrocautery tonsillectomy.

The aim of this study was to assess the effect of a single dose of dexamethasone on postoperative vomiting and pain in children undergoing tonsillectomy using a standardized anesthetic technique.

\section{Methods}

Approval was given by the local Ethics Committee and informed parental written consent was obtained. One hundred twenty patients, four to $11 \mathrm{yr}$ old undergoing tonsillectomy with or without adenoidectomy were included in this study. Children who received antiemetics, steroids, anti-histaminic, or psychoactive drugs during the week before surgery were excluded from the study.

The study design was randomized, double-blind, and placebo-controlled. Patients were prospectively randomized to receive either dexamethasone 0.5 $\mathrm{mg} \cdot \mathrm{kg}^{-1}$ iv (maximum dose $8 \mathrm{mg}$ ) or an equivalent volume of saline. Study drugs were marked only with a coded number label. A computer-generated table of numbers guided randomization. Study drugs were given immediately after $i v$ access was established by the anesthesiologist, who was unaware of drug identity.

Patients were not allowed solid food for eight hours before operation; clear liquids were permitted until three hours before surgery. A standard anesthetic technique was used. Premedication with oral midazolam 0.5 $\mathrm{mg} \cdot \mathrm{kg}^{-1}$ (maximal dose $20 \mathrm{mg}$ ) was given $20 \mathrm{~min}$ preoperatively. Anesthesia was induced with sevoflurane and $60 \%$ nitrous oxide in oxygen via mask followed by insertion of an iv cannula. Suxamethonium $1 \mathrm{mg} \cdot \mathrm{kg}^{-1}$ was used to facilitate intubation. A mixture of sevoflurane in nitrous oxide and oxygen $\left(\mathrm{FIO}_{2}=0.4\right)$ was administered via a T-piece or Bain system for maintenance of anesthesia. All children received fentanyl 1 $\mu \mathrm{g} \cdot \mathrm{kg}^{-1}$ before surgery started and $20 \mathrm{~mL} \cdot \mathrm{kg}^{-1}$ lactated Ringer's solution during operation. All patients breathed with gentle hand-assisted ventilation. The heart rate (ECG), arterial oxygen saturation $\left(\mathrm{SpO}_{2}\right)$, blood pressure, temperature and end-tidal $\mathrm{CO}_{2}$ were monitored. The same surgeon, using an electrodissection technique, performed all operations. At the end of surgery, gastric contents were suctioned via an orogas- tric tube before extubation. The trachea was extubated when the child was awake. All children were transferred to the postanesthesia care unit (PACU). The criteria for discharge from PACU to ward included stable vital signs, adequate pain control, and absence of vomiting for one hour.

Pain was assessed in the PACU by an independent observer, using both a five point 'faces' scale $(1=$ no pain, $\mathbf{5}=$ highest pain score), and the Children's Hospital Eastern Ontario Pain Scale (CHEOPS; range of score 4-13), at $30 \mathrm{~min}$, one, two, and four hours after extubation. Pain was assessed in the ward by children on a visual analogue toy at six, 12 and, $24 \mathrm{hr}$ postoperatively. All children were shown the visual analogue toy during the preoperative visit, and its use was explained. This instrument is in the form of a chart, containing different animal figures increasing in size from bird $(0$, bottom $=$ no pain $)$ to elephant $(10$, top $=$ worst pain), in ten steps. One nurse blinded to treatment group also assessed the patients' pain with a standard visual analogue scale at six-hour intervals postoperatively at rest and while drinking $50 \mathrm{~mL}$ of water. Pain assessment by the nurse was based on six main components: i) direct questioning of pain at rest and during swallowing; ii) moisture and colour of the skin; iii) vocalization; iv) movements; v) response to handling; and vi) measurement of cardiovascular variables, ${ }^{7}$ respiratory rate and pulse oxymetry. Parents were instructed to assist the nurse in her assessment because they knew their child's behaviour best. The time and dosage of postoperative analgesics received was also recorded.

Time to awaken (from the end of anesthesia until the patients opened their eyes on command) and time to the first administration of postoperative analgesia were recorded. Postoperative pain relief was obtained with rectal paracetamol $30 \mathrm{mg} \cdot \mathrm{kg}^{-1}$ repeated every six hours as necessary (maximum dose $90 \mathrm{mg} \cdot \mathrm{kg}^{-1} \cdot \mathrm{day}^{-1}$ ). Pethidine in a titrated dose (total $1 \mathrm{mg} \cdot \mathrm{kg}^{-1}$ ) was administered $i v$ for rapid pain relief to patients with a CHEOPS score $>7$ or who were crying during two consecutive five-minute observation periods until the child was comfortable. Water was offered to children one hour after arrival in the PACU and at the child's request. Intravenous fluid infusion was continued until adequate oral intake (oral ingestion of $100 \mathrm{~mL}$ of fluids and $100 \mathrm{~mL}$ of soft food within four hours). Duration of PACU stay, time to first oral intake and volume of $i v$ fluid infusion were recorded. The quality of oral intake was assessed by the child if aged over seven years or the parent using the following scale: $1=$ child requests food, 2 = child accepts food when offered, $3=$ child accepts food when coaxed, $4=$ child refuses food. The 
TABLE I Patient demographic and clinical data

\begin{tabular}{|c|c|c|}
\hline Characteristics & $\begin{array}{l}\text { Saline group } \\
(n=55)\end{array}$ & $\begin{array}{l}\text { Dexamethasone group } \\
(n=55)\end{array}$ \\
\hline Age $(\mathrm{yr})$ & $5.1(2.7)$ & $5.2(2.5)$ \\
\hline Weight (kg) & $19.4(4.3)$ & $20.0(5.9)$ \\
\hline $\operatorname{Sex}(M / F)$ & $32 / 23$ & $29 / 26$ \\
\hline ASA physical status (I-II) & $51 / 4$ & $50 / 5$ \\
\hline \multicolumn{3}{|l|}{ Type of surgery $(n)$} \\
\hline -Tonsillectomy ' $\mathrm{T}$ ' & 4 & 5 \\
\hline -'T' + Adenoidectomy 'A' & 46 & 44 \\
\hline -' $\mathrm{T}$ ' + 'A' + myringotomy ' $\mathrm{M}$ ' & 5 & 6 \\
\hline \multicolumn{3}{|l|}{ History of PONV or motion } \\
\hline -Sickness $(n)$ & 5 & 4 \\
\hline \multicolumn{3}{|l|}{ Intraoperative } \\
\hline -Fentanyl $\left(\mu \mathrm{g} \cdot \mathrm{kg}^{-1}\right)$ & $1.12(0.1)$ & $1.11(0.4)$ \\
\hline -Fluids $\left(\mathrm{mL} \cdot \mathrm{kg}^{-1}\right)$ & $19.7(5.5)$ & $17.9(5.5)$ \\
\hline Duration of surgery $(\mathrm{min})$ & $33.5(8.3)$ & $34.6(9.1)$ \\
\hline
\end{tabular}

Values are expressed as number $(n)$, or mean $( \pm \mathrm{SD})$. PONV $=$ postoperative nausea and vomiting.

nurse recorded the incidence of vomiting. Repeated vomiting within a one- to two-minute period was recorded as a single emesis. Nausea was not recorded because it is difficult to assess in children. Vomiting occurring more than twice was treated with metoclopramide $0.15 \mathrm{mg} \cdot \mathrm{kg}^{-1}$ iv The presence or absence of any side effect such as bleeding, fever, flushing or headache was noted.

A sample size calculation performed before the commencement of the study revealed that 55 patients per group would be required to detect a $50 \%$ reduction in the incidence of postoperative vomiting, assuming a $50 \%$ baseline incidence of vomiting after tonsillectomy in the control group $(\alpha=0.05$ and $\beta=$ 0.20 ). Groups were compared using Student's t test or Chi-squared test for contingency tables as appropriate. Visual analogue scores, time to awaken and time to first postoperative analgesia were analyzed using Mann-Whitney U test. Differences within groups were subjected to the Wilcoxon signed rank test. A $P$ value $<0.05$ was considered statistically significant.

\section{Results}

Ten patients were excluded from data analysis, eight because of protocol violations and two because of immediate postoperative bleeding requiring surgical intervention. Demographic characteristics of the remaining 110 patients, anesthetic duration, and type of surgery were not different between the two groups (Table I).

Time to awaken was comparable in the two groups. The time to the first administration of postoperative

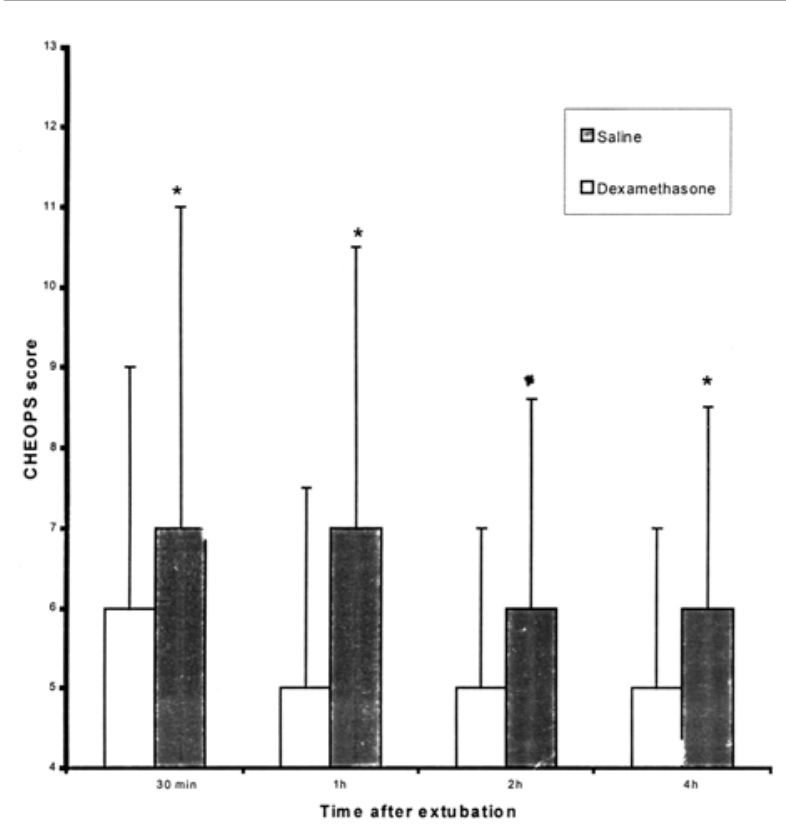

FIGURE 1 Median Children's Hospital Eastern Ontario Pain Scale (CHEOPS) scores at $30 \mathrm{~min}$, one, two, and four hours after extubation, ${ }^{*} P<0.05$.

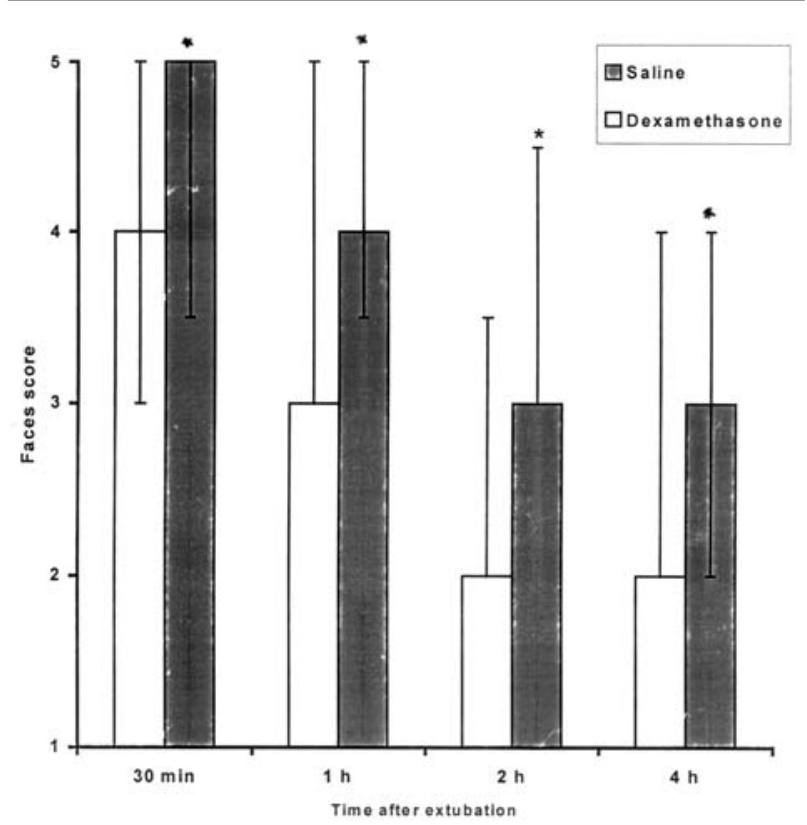

FIGURE 2 Median 'Faces' pain score at $30 \mathrm{~min}$, one, two, and four hours after extubation, ${ }^{*} P<0.05$. 
TABLE II Time to awaken and to first analgesic demand, duration of PACU stay, VAS on the ward, and analgesic requirement

\begin{tabular}{lll}
\hline & $\begin{array}{l}\text { Saline group } \\
(n=55)\end{array}$ & $\begin{array}{l}\text { Dexamethasone group } \\
(n=55)\end{array}$ \\
\hline Time to awaken (hr) & $0.37(0.08)$ & $0.4(0.05)$ \\
Time to first analgesia (hr) & $0.59(0.2)$ & $1.48(0.22)^{* *}$ \\
Duration of PACU stay (hr) $)$ & $3.19(0.34)$ & $2.59(0.31)^{*}$ \\
VAS by nurse & & \\
-At 6 hr: resting & $3.1(1.9)$ & $1.1(1.1)^{*}$ \\
-Drinking & $4.7(2.4)$ & $2.5(2.5)^{*}$ \\
VAS by children & & \\
-At 6 hr: resting & $3.5(1.6)$ & $1.4(0.8)^{*}$ \\
-Drinking & $5.1(2.4)$ & $3.0(1.5)^{*}$ \\
-At 12 hr: resting & $2.9(1.0)$ & $0.8(0.5)^{* *}$ \\
-Drinking & $3.7(2.7)$ & $1.1(1.9)^{* *}$ \\
-At 24 hr: resting & $2.9(0.9)$ & $0.8(0.4)^{* *}$ \\
-Drinking & $3.2(1.9)$ & $1.1(0.8)^{* *} \dagger$ \\
Analgesic $\left(m g \cdot k g^{-1}\right)$ & & \\
-Rectal paracetamol & $85(22)$ & $55(12)^{*}$ \\
-Pethidine $(n=9$ patients $)$ & $0.6(0.1)$ & -- \\
\hline
\end{tabular}

Values given as mean $( \pm \mathrm{SD}) ;{ }^{*} P<0.05 ;{ }^{*} P<0.01$; saline $v s$ dexamethasone; $\dagger P<0.05$ within group as compared to value at six hours. PACU $=$ postanesthesia care unit; VAS $=$ visual analogue scale.

TABLE III Incidence and severity of PONV

\begin{tabular}{lll}
\hline PONV outcome & $\begin{array}{l}\text { Saline group } \\
(n=55)\end{array}$ & $\begin{array}{l}\text { Dexamethasone group } \\
(n=55)\end{array}$ \\
\hline $\begin{array}{l}\text { Early PACU } \\
\text {-None }\end{array}$ & $35(64)$ & $47(85)^{*}$ \\
-Once & $14(25)$ & $6(11)$ \\
-Multiple & $6(11)$ & $2(4)$ \\
- Rescue antiemetic & $6(11)$ & $2(4)$ \\
Late (up to 24 hr) & & \\
-None & $34(62)$ & $50(91)^{* * *}$ \\
-Once & $15(27)$ & $3(5)$ \\
-Multiple & $6(11)$ & $2(4)$ \\
-Rescue antiemetic & $6(11)$ & $0(0)^{*}$ \\
Total & & \\
-Overall PONV & $31(56)$ & $11(20)^{* * *}$ \\
-Rescue antiemetic & $12(22)$ & $2(4)^{* *}$ \\
\hline
\end{tabular}

Values are expressed as the number $(\%)$ of children. ${ }^{*} P<0.05 ;{ }^{*} P$ $<0.01 ;{ }^{* *} P<0.001$; saline $v s$ dexamethasone. PACU $=$ postanesthesia care unit; PONV = postoperative nausea and vomiting.

analgesics was longer in the dexamethasone group than in the control group $(P<0.01)$. Duration of stay in the PACU was longer in the control group than in the dexamethasone group $(P<0.05)$. Both CHEOPS (Figure $1)$ and 'faces' (Figure 2) pain scores were lower $(P<$ $0.05)$ in the dexamethasone group at $30 \mathrm{~min}$ and up to four hours after extubation. All children properly understood the visual analogue toy. At six hours postoperatively, children in the dexamethasone group had lower pain scores at rest and during drinking compared
TABLE IV Time to first oral intake, duration and volume of iv fluid, and incidence of adverse events

\begin{tabular}{lll}
\hline & $\begin{array}{l}\text { Saline group } \\
(n=55)\end{array}$ & $\begin{array}{l}\text { Dexamethasone group } \\
(n=55)\end{array}$ \\
\hline $\begin{array}{l}\text { Time to first oral intake (hr) } \\
\text { Duration of } i v \text { fluid }(\mathrm{hr})\end{array}$ & $\begin{array}{l}1.3(0.7) \\
16.1(6.1)\end{array}$ & $\begin{array}{l}0.4(0.2)^{* *} \\
9.3(4.4)^{* *}\end{array}$ \\
$\begin{array}{l}\text { Fluid volume } \mathrm{mL} \cdot \mathrm{kg}^{-1} \\
\text { Quality of oral intake at } 12 \text { hr after surgery }\end{array}$ & $36(7)^{*}$ \\
$\begin{array}{l}\text { Grade } 1+2 n(\%) \\
\text { Adverse events } n(\%)\end{array}$ & $35(64)$ & $46(84)^{*}$ \\
-Secondary bleeding & 0 & 0 \\
-Fever & 0 & 0 \\
-Flushing & $2(4)$ & $1(2)$ \\
-Headache & $3(5)$ & $2(4)$ \\
\hline
\end{tabular}

All values given as mean $( \pm S D)$, except in quality of oral intake and adverse events that are expressed as the number (\%) of children.

to the control group $(P<0.05)$. At 12 and 24 hr postoperative swallowing was still significantly less painful in the dexamethasone group than in the control group $(P$ $<0.01)$. Mean pain scores during drinking in the dexamethasone group was lower in the late postoperative period $(24 \mathrm{hr})$ than at six hours after surgery $(P<0.05)$. Mean pain scores reported by the nurse at six hour intervals were similar to those reported by the child. No child in the dexamethasone group required postoperative pethidine supplementation compared to nine children in the control group (Table II).

The administration of dexamethasone significantly reduced the overall incidence of postoperative vomiting from $56 \%$ to $20 \%$ when compared with saline $(P<$ $0.001)$. Eight patients $(15 \%)$ in the dexamethasone group vomited in the PACU (early vomiting), compared with 20 patients $(36 \%)$ in the saline group $(P<$ $0.05)$. The incidence of vomiting during stay on the ward (late vomiting) was more frequent in the saline group $(P<0.001)$. Eight children $(15 \%)$ in the dexamethasone group vomited in the PACU, while only three $(5 \%)$ vomited during the late postoperative period (on the ward). Twelve patients in the saline group vomited more than two times (three to six episodes) and needed a rescue antiemetic compared with two patients in the dexamethasone group (Table III). The severity of late vomiting (requirement for a rescue antiemetic) was significantly less in the dexamethasone group $(0 \%)$ than in the saline group $(11 \% ; P<0.05)$. There were no children in the dexamethasone group who required antiemetic rescue on the ward while two (4\%) patients required treatment with metoclopramide in the PACU. The time to the first oral intake was significantly shorter and the quality of intake was 
significantly better in the dexamethasone group $(P<$ 0.01 , and $P<0.05$ respectively; Table IV).

The incidence of side effects during a $24 \mathrm{hr}$ observation period was comparable in the two groups. No bleeding was reported the day after the surgery in any patient (Table IV).

\section{Discussion}

This investigation shows a decrease in the incidence of postoperative early and late vomiting, as well as an improvement in postoperative pain scores and quality of oral intake during the first $24 \mathrm{hr}$ after tonsillectomy in children who received dexamethasone $0.5 \mathrm{mg} \cdot \mathrm{kg}^{-1}$ iv after induction of anesthesia compared with those who received placebo.

Several studies failed to demonstrate any beneficial effect of dexamethasone on the incidence of postoperative vomiting or pain after tonsillectomy in children. ${ }^{8-10}$ These studies included a limited number of patients and anesthetic and antiemetic protocols were not standardized. Postoperative nausea and vomiting are a multifactorial problem and several anesthetic and nonanesthetic factors must be controlled to obtain meaningful results. In the present study, sample size was predetermined and anesthetic technique, amount of $i v$ hydration, dose of narcotic analgesic, antiemetic therapy and duration of hospital stay were standardized. We found that dexamethasone $0.5 \mathrm{mg} \cdot \mathrm{kg}^{-1}$ up to $8 \mathrm{mg}$ administered before tonsillectomy markedly decreased vomiting in children both in the PACU (early vomiting) and on the ward up to $24 \mathrm{hr}$ after surgery (late vomiting). Dexamethasone may exert an antiemetic action via prostaglandin antagonism, ${ }^{11}$ serotonin inhibition in the gut, ${ }^{12}$ and release of endorphins. ${ }^{13}$

Aouad et al. ${ }^{14}$ and Pappas et al. ${ }^{15}$ have reported a significant decrease in the incidence of vomiting in dexamethasone treated children only during delayed recovery. In Splinter and Roberts' study, ${ }^{16}$ dexamethasone decreased vomiting in children after tonsillectomy both during early PACU recovery and delayed $(24 \mathrm{hr})$ recovery. The children who received propofol on induction of anesthesia in the previous study had a decreased incidence of early vomiting when compared to those who had an inhaled induction. This may be due to an interaction between dexamethasone and propofol. In the present study, the decrease in the incidence of early vomiting and pain might be attributed to potentiation of opioid analgesia by dexamethasone. The analgesic and antiemetic effects of dexamethasone were more pronounced in the late postoperative period, which is consistent with its prolonged biological half-life of 36 to $48 \mathrm{hr}$.

The dose of dexamethasone used in the present study was similar to that reported in a recent study of patients undergoing tonsillectomy. ${ }^{14}$ Complete antiemetic response was reported to be $60 \%$ with dexamethasone $0.15 \mathrm{mg} \cdot \mathrm{kg}^{-1}$ (maximum dose, $8 \mathrm{mg}$ ), ${ }^{16}$ $76 \%$ with dexamethasone $1 \mathrm{mg} \cdot \mathrm{kg}^{-1}$ (maximum dose, $25 \mathrm{mg}$ ) ${ }^{15} 77 \%$ with dexamethasone $0.5 \mathrm{mg} \cdot \mathrm{kg}^{-1}$ (maximum dose, $8 \mathrm{mg})^{14}$ and $80 \%$ with our regimen. There was a remarkably low incidence of postoperative vomiting of $5 \%$, with the combination of dexamethasone plus a low dose of ondansetron after strabismus surgery in children when compared with dexamethasone alone. ${ }^{17}$ To minimize the incidence of postoperative vomiting and improve oral intake after tonsillectomy, anesthesiologists have focused primarily on anesthetic technique and other perioperative factors with minimal emetogenic potential and on preoperative dexamethasone administration $\left(0.5 \mathrm{mg} \cdot \mathrm{kg}^{-1}\right.$ iv up to $\left.8 \mathrm{mg}\right)$.

The clinical evaluation of postoperative pain in children is difficult. We used both the faces and CHEOPS pain scales to cross-validate the results, especially in the PACU. ${ }^{18}$ We used a visual analogue scale on the ward as it is more sensitive than simple descriptive scales and can be used in children four to five years old. We found that preoperative dexamethasone administration improves pain scores, reduces analgesic requirements, allows earlier oral fluid intake, and improves postoperative swallowing and the quality of oral intake. These results may be attributed to the anti-inflammatory effect produced by dexamethasone, which may reduce local edema and pain. These results on the analgesic effect of dexamethasone are in agreement with previous studies of dental ${ }^{19,20}$ and ambulatory surgery. ${ }^{21}$ Inconclusive results in other studies may be due to difficulties in standardizing perioperative clinical condition, the use of analgesics in the control groups and insensitive methods to assess pain. We limited our study to standardized surgical and anesthetic procedures and perioperative analgesics were adjusted to reveal any differences in analgesic consumption. Combined assessment by child, nurse, and parents as applied in our study may be a valid means of improving the validity of pain scoring in children. ${ }^{22}$

The long-term administration of corticosteroids is associated with adverse events, such as increased risk of infection, delayed wound healing, glucose intolerance, adrenal suppression, and a vascular necrosis of the hip or other joints. Although a single dose of dexamethasone is considered safe, further studies with longer follow-ups are indicated.

In conclusion, a prophylactic intraoperative single dose $\left(0.5 \mathrm{mg} \cdot \mathrm{kg}^{-1} i v\right.$ up to $\left.8 \mathrm{mg}\right)$ of dexamethasone decreases the incidence of early and late postoperative vomiting, reduces pain scores at rest as well as during swallowing and improves the quality of oral intake in 
children during the first $24 \mathrm{hr}$ after electrodissection tonsillectomy without apparent side effects.

\section{References}

1 Litman RS, Wu CL, Catanzaro FA. Ondansetron decreases emesis after tonsillectomy in children. Anesth Analg 1994; 78: 478-81.

2 Furst SR, Rodarte A. Prophylactic antiemetic treatment with ondansetron in children undergoing tonsillectomy. Anesthesiology 1994; 81: 799-803.

3 Ferrari LR, Donlon JV. Metoclopramide reduces the incidence of vomiting after tonsillectomy in children. Anesth Analg 1992; 75: 351-4.

4 Weimert TA, Babyak JW, Richter HJ. Electrodissection tonsillectomy. Arch Otolaryngol Head Neck Surg 1990; 116: 186-8.

5 Jones AL, Hill AS, Soukop M, et al. Comparison of dexamethasone and ondansetron in the prophylaxis of emesis induced by moderately emetogenic chemotherapy. Lancet 1991; 338: 483-7.

6 April MM, Callan ND, Nowak DM, Hausdorff MA. The effect of intravenous dexamethasone in pediatric adenotonsillectomy. Arch Otolaryngol Head Neck Surg 1996; 122: 117-20.

7 Maunuksela EL, Olkkola KT, Korpela R. Measurement of pain in children with self-reporting and behavioral assessment. Clin Pharmacol Ther 1987; 42: 137-41.

8 Ohlms LA, Wilder RT, Weston B. Use of intraoperative corticosteroids in pediatric tonsillectomy. Arch Otolaryngol Head Neck Surg 1995; 121: 737-42.

9 Catlin FI, Grimes WJ. The effect of steroid therapy on recovery from tonsillectomy in children. Arch Otolaryngol Head Neck Surg 1991; 117: 649-52.

10 Volk MS, Martin P, Brodsky L, Stanievich JF, Ballou M. The effects of preoperative steroids on tonsillectomy patients. Otolaryngol Head Neck Surg 1993; 109: 726-30.

11 Rich WM, Abdulhayoglu G, DiSaia PJ. Methylprednisolone as an antiemetic during cancer chemotherapy - a pilot study. Gynecol Oncol 1980; 9: 193-8.

12 Fredrikson M, Hursti T, Furst CJ, et al. Nausea in cancer chemotherapy is inversely related to urinary cortisol excretion. Br J Cancer 1992; 65: 779-80.

13 Harris AL. Cytotoxic-therapy-induced vomiting is mediated via enkephalin pathways. Lancet $1982 ; 1$ : 714-6.

14 Aouad MT, Siddik SS, Rizk LB, Zaytoun GM, Baraka $A S$. The effect of dexamethasone on postoperative vomiting after tonsillectomy. Anesth Analg 2001; 92: 636-40.

15 Pappas ALS, Sukbani R, Hotaling AJ, et al. The effect of preoperative dexamethasone on the immediate and delayed postoperative morbidity in children undergoing adenotonsillectomy. Anesth Analg 1998; 87: 57-61.

16 Splinter WM, Roberts DJ. Dexamethasone decreases vomiting by children after tonsillectomy. Anesth Analg 1996; 83: 913-6.

17 Splinter WM. Prevention of vomiting after strabismus surgery in children: dexamethasone alone versus dexamethasone plus low-dose ondansetron. Paediatr Anaesth 2001; 11: 591-5.

18 Suraseranivongse S, Santawat U, Kraiprasit K, Petcharatana S, Prakkamodom S, Muntraporn N. Cross-validation of a composite pain scale for preschool children within 24 hours of surgery. Br J Anaesth 2001; 87: 400-5.

19 Baxendale BR, Vater M, Lavery KM. Dexamethasone reduces pain and swelling following extraction of third molar teeth. Anaesthesia 1993; 48: 961-4.

20 Skjelbred P, Lokken P. Post-operative pain and inflammatory reaction reduced by injection of a corticosteroid. Eur J Clin Pharmacol 1982; 21: 391-6.

21 Aasboe V, Raeder JC, Groegaard B. Betamethasone reduces postoperative pain and nausea after ambulatory surgery. Anesth Analg 1998; 87: 319-23.

22 Elhakim M, Abdul Salam AY, Eid A, Kaschef N, Mostafa BE. Inclusion of pethidine in lidocaine for infiltration improves analgesia following tonsillectomy in children. Acta Anaesthesiol Scand 1997; 41: 214-7. 